This item was submitted to Loughborough's Research Repository by the author.

Items in Figshare are protected by copyright, with all rights reserved, unless otherwise indicated.

\title{
Plate-out in PVC extrusion. I. Analysis of plate-out
}

PLEASE CITE THE PUBLISHED VERSION

PUBLISHER

John Wiley \& Sons

LICENCE

CC BY-NC-ND 4.0

\section{REPOSITORY RECORD}

Gilbert, Marianne, Neil Varshney, Koen van Soom, and Michael Schiller. 2008. "Plate-out in PVC Extrusion. I. Analysis of Plate-out". figshare. https://hdl.handle.net/2134/3266. 
This item was submitted to Loughborough's Institutional Repository by the author and is made available under the following Creative Commons Licence conditions.

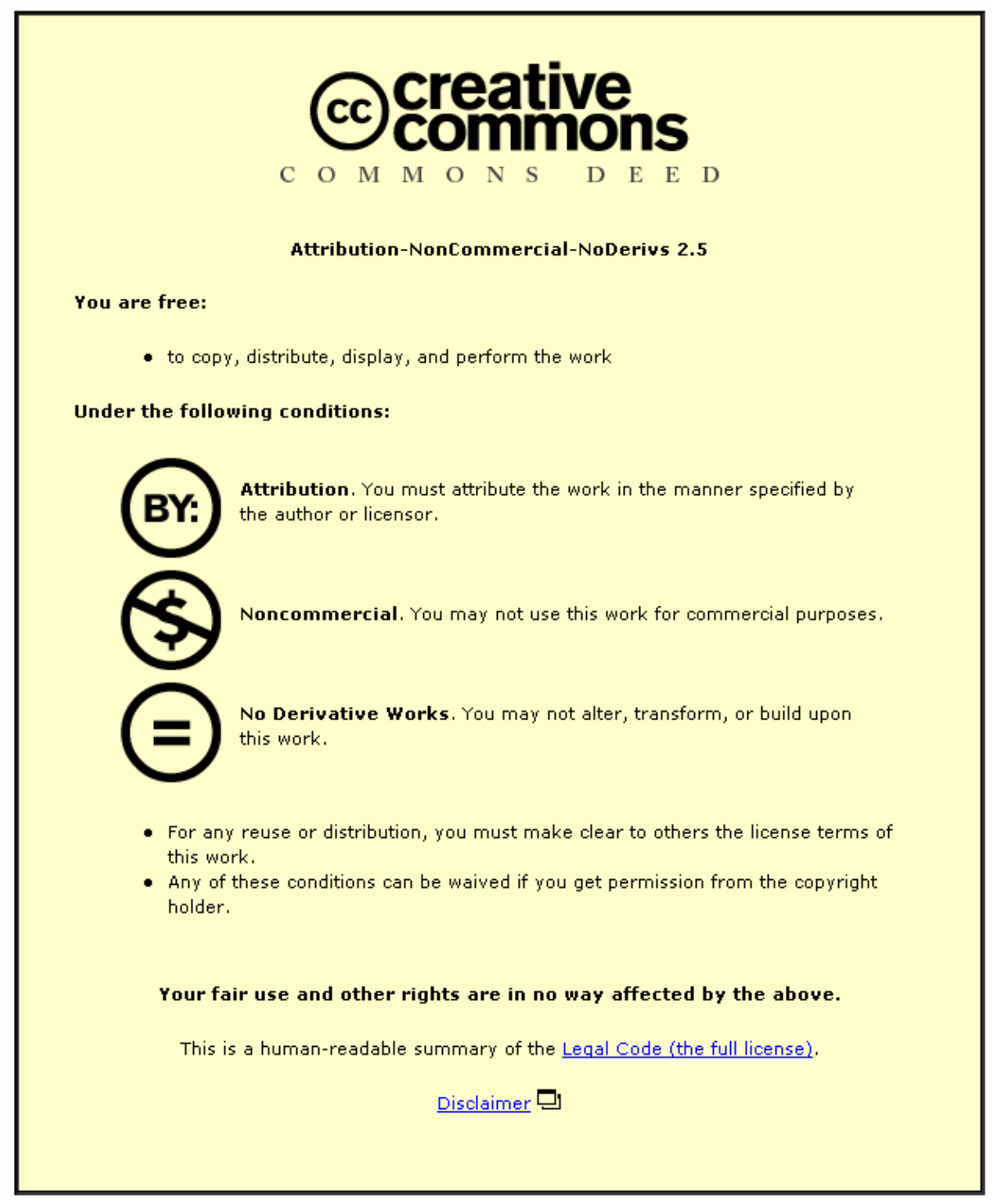

For the full text of this licence, please go to: http://creativecommons.org/licenses/by-nc-nd/2.5/ 


\section{Plate-out in PVC Extrusion - I Analysis of plate-out M Gilbert ${ }^{\mathrm{a}}$, N Varshney ${ }^{\mathrm{b}}$, K Van Soom ${ }^{\mathrm{c}}$, M Schiller ${ }^{\mathrm{d}}$}

\section{Abstract}

Samples of extruder plate-out from industrial rigid PVC production lines have been investigated using a number of analytical techniques. The combined use of SEM-EDX (scanning electron microscopy energy dispersive x-ray analysis), thermal analysis, FTIR (Fourier Transform infra Red spectrophotometry) and LIMA (laser induced mass analysis) has enabled most plate-out components to be identified, and linked to likely formulation ingredients. FTIR and thermal analysis were used to identify organic components. FTIR was also useful for identifying some inorganic compounds present in sufficient quantities, while EDX detected elements present. LIMA was the most sensitive technique, detecting trace quantities of both cations and anions. Calcium carbonate, titanium dioxide and lead stabilizers were found in all die plate-out samples studied, together with small amounts of lubricants.

\section{Introduction}

Plate-out is a well known problem with respect to rigid PVC extrusion [1-9]. It may be defined as the formation of unwanted deposits anywhere in an extrusion line. Attention was

\footnotetext{
${ }^{a}$ Institute of Polymer Technology and Materials Engineering, Lough borough University, Loughborough, Leics LE11 3TU, UK.

${ }^{\mathrm{b}}$ Wavin Plastics Ltd., Parsonage Way, Chippenham, Wiltshire, SN15 5PN.

${ }^{\mathrm{c}}$ Honeywell Belgium, N.V.Haasrode, Research Park, Grauwmeer 1, B-3001 Heverlee, Belgium.

${ }^{d}$ Chemson Polymer - Additive AG, Industriestraße 19, 9601 Arnoldstein, Austria.
} 
focussed on this topic in the late 1970s and early 1980s, for example references [1-5]. It was found that both formulation and processing conditions affect plate-out formation. Parey $[1,2]$ discussed effects due to mixing conditions and the surface structure of PVC, although these factors have not been considered by other workers. It was established by a number of workers $[3,4,6]$ that plate-out consisted mainly of inorganic materials, including particularly titanium dioxide, calcium carbonate, and tribasic lead sulfate. Organic components were found to include organics from calcium stearate, waxes, plasticizer, and some PVC. In other words, the composition of plate-out is vastly different from the PVC formulation itself. Plate-out is observed for many formulations; although it has been suggested that it is particularly severe for lead formulations, a survey of the literature actually suggests that it is found with most stabilizer types. Parey $[1,2]$ suggested that formulations containing liquid stabilizers are more resistant to plate-out than those containing solid stabilizers. Pointe [3] analyzed PVC extrusions and compression moldings, and found that the composition of inorganics was lower at the surfaces, which was attributed to separation of inorganic material via migration. There is general agreement that the amount of plate-out increases as melt temperature increases $[1-3,7]$. This has been attributed to the reduction in melt viscosity that promotes migration. The most detailed mechanism for the production of plate-out is that proposed by Lippoldt [4]. This mechanism, which is becoming increasingly widely accepted, is based on the assumption that organic components, particularly hydrocarbons, act as a 'carrier' for inorganics. The mechanism proposed for the tin stabilized formulation used by Lippoldt consists of five stages, which may be summarized as follows:

(i) molten hydrocarbon dissolves stabilizer; (ii) at temperatures above $175^{\circ} \mathrm{C}$ calcium stearate dissolves in this mixture to produce a complex; (iii) this complex is adsorbed on to the polar surfaces of inorganic additives, rendering them less polar; (iv) in decompression zones in the extruder, the above conglomerates are released from the polymer melt. The 
reduction in pressure results in a decrease in temperature to below $175^{\circ} \mathrm{C}$, so precipitation occurs; (v) the separated gel-inorganic mixture deposits on metal surfaces and loses hydrocarbon. This provides a region on which further material deposits, and the process is continued.

$175^{\circ} \mathrm{C}$ was also recognised as a critical temperature by Parey, who found that for a lead stabilized formulation, plate-out was particularly severe in the temperature range $175^{\circ} \mathrm{C}$ $195^{\circ} \mathrm{C}$, which he related to the region in which primary particles are present in the PVC melt. Leskovyansky [5] discussed the contribution of oxidized metal surfaces to plate-out production.

The formation of plate-out has been re-visited more recently [6-9]. Bussman et al [6] examined various $\mathrm{Ca} / \mathrm{Zn}$ stabilized formulations and attributed plate-out formation to oxidation of iron in the steel extruder barrel, causing a rough surface, to which excess lubricant migrated causing a build-up. Unlike other workers, they related plate-out to the thermal stability of different formulations, and considered that plate-out was produced in high pressure, rather than low pressure regions in the extruder. Bos et al [7] reviewed the factors that affect plate-out formation, and discussed the differences between die plate-out and calibration plate-out. Once again, they mentioned the effect of the barrel surface. Holtzen and Musiano [8] considered the effect of polymer melt rheology, and used dies of varying design to identify positions at which plate-out originated.

Several workers observed that increasing the amount of filler such as $\mathrm{CaCO}_{3}$ had the effect of reducing the amount of plate-out, and this was attributed to abrasive action on the walls of the extruder $[3,6,7,10]$. For this reason, anti-plate-out additives have been developed. Of these, fine particle silicas are probably the most common [11,12]. Increasing $\mathrm{TiO}_{2}$ however increased plate-out [10] which was unexpected. Schiller et al [10] also investigated the influence of a number of processing conditions and formulation ingredients on plate-out. 
They showed that Lippoldt's mechanism also applied to lead based compounds, and that PE waxes, calcium and lead stearates form alloys. A higher extrusion torque caused more plateout, and plate out was also increased by the presence of small amount of moisture.

This paper describes a group of techniques which, when used together are capable of analyzing small samples of plate-out collected during PVC extrusion [13]. Samples examined were obtained from commercial extrusion lines. Results from these samples provide further evidence about plate out composition.

\section{Experimental}

\section{Samples}

As a result of a request to a number of processors, samples of plate-out were obtained and subsequently analyzed. In some cases several grams of sample were available, while other samples were less than one gram in weight. Details of these samples are listed in Table 1.

\section{Characterization of plate-out samples}

\section{Methods used}

The above plate-out samples were characterized by the following techniques:

\section{DSC}

Samples were heated at $10^{\circ} \mathrm{C} / \mathrm{min}$ to $220^{\circ} \mathrm{C}$ in a $910 \mathrm{DSC}$ cell attached to a TA Instruments Thermal Analyst 2000. This technique enables any crystalline materials to be detected and possibly identified.

\section{SEM-EDX}


Samples were gold coated and observed with a Cambridge Instruments Stereoscan 360 with an EDX analyzer. This enabled elements present in the plate-out to be identified.

FTIR Samples were ground with IR grade potassium bromide powder, and IR spectra obtained using a Mattson 3000 FTIR spectrometer, fitted with a diffuse reflectance (DRIFT) attachment. The presence of organic material can be readily identified; calcium carbonate and calcium stearate also give characteriztic spectra.

LIMA Small fragments of plate-out were examined using a Cambridge Mass Spectrometry Laser Induced Ion Mass Analyzer. In this technique a pulsed UV laser is used to remove material from a sample surface. This ionized material passes into a mass spectrometer for analysis. The sample area analyzed is $1-2 \mu \mathrm{m}$ in diameter, and about $0.25 \mu \mathrm{m}$ deep. Both cations and anions can be detected, as well as various chemical groups. This method is extremely sensitive so can provide a considerable amount of information for very small samples.

DSC traces and FTIR spectra were also obtained for various PVC additives to serve as standards, thus aiding the identification of unknown samples.

\section{Results and Discussion}

Summary data for the plate-out samples is shown in Table 2 . Selected data for the samples examined will be discussed. A typical plate out sample PO1 is shown in Fig 1. DSC traces of the dark and light material in PO1 are shown in Figs 2 and 3. Both show two melting peaks in the region of $40-55^{\circ} \mathrm{C}$, while Fig 2 shows additional minor peaks at higher temperatures. The ratio of the major peaks at $40^{\circ} \mathrm{C}$ and $52^{\circ} \mathrm{C}$ differs in the two samples. Pure stearic and palmitic acids have melting temperatures of $69^{\circ} \mathrm{C}$ and $63^{\circ} \mathrm{C}$, but these values are reduced in mixtures which would be used in lubricants. This identification was confirmed by GC-MS 
analysis. Infra red analysis of this sample suggested that hydrocarbon wax or polyethylene was also present, possibly accounting for the minor DSC peak at $80-85^{\circ} \mathrm{C}$. This sample was predominantly organic, but LIMA, which is extremely sensitive demonstrated the presence of minor amounts of inorganic components as indicated in Table 2. The phosphite and phosphate anions are likely to originate from lead phosphite, since this plate-out was obtained from a lead stabilized compound. Sample PO1 was obtained from the calibrator. Previous work[15] has shown that calibrator plate-out is normally organic, produced by volatilization and condensation or from the surface of the hot extruded product.

Backscattered SEM images of die plate-out samples PO3 - PO8 are shown in Fig 4. The physical composition of plate-out varies considerably, and is generally heterogeneous, containing regions with different compositions, implying that a number of different components were deposited from the melt. The various samples will be considered individually.

The absence of DSC melting peaks below $220^{\circ} \mathrm{C}$ for sample PO3 suggested that organic components were absent, an observation confirmed by FTIR. The SEM image of this sample is shown in Fig 4a. It consists of light flake particles on a dark substrate. EDX analysis revealed that the flakes were rich in lead, sulphur, phosphorus and chlorine, consistent with a lead stabilized formulation. The darker areas were rich in titanium, lead and phosphorus. No calcium was detected by EDX, but the small amount detected by LIMA could be attributed to calcium stearate. $\mathrm{CaCl}$ anions were also present from reaction with chlorine ions from degraded PVC. Again ions were detected by LIMA and phosphorous oxide by FTIR. The appearance of the PO4 plate-out was rather different in that clear stripes are observed on the flakes in the SEM image (Fig 4b). This effect has been attributed to to preferential deposition of additives at striations along the die flow channel [14]: the light areas were lead 
related while the darker regions were composed of both $\mathrm{CaCO}_{3}$ and $\mathrm{TiO}_{2}$. LIMA also showed that the sample was rich in lead, calcium and titanium based species, and a weak DSC melting peak at $140^{\circ} \mathrm{C}$ was typical of calcium stearate. The infra red spectrum corresponded to a mixture of titanium dioxide and calcium carbonate. PO5 was allegedly from the same extrusion run, but differed in color and appearance (Fig 4c). Analysis by EDX and LIMA did however show that both PO4 and PO5 were composed of the same inorganic components but thermal analysis did not provide any evidence of calcium stearate. DRIFT again detected mostly $\mathrm{CaCO}_{3}$ and $\mathrm{TiO}_{2}$ (Fig 5) with additional absorbances at 2920, $2851 \mathrm{~cm}^{-1}$ (both $\mathrm{CH}_{2}$ ), $1732 \mathrm{~cm}^{-1}\left(\mathrm{C}=\mathrm{O}\right.$, major peak for carboxylate) and $1022 \mathrm{~cm}^{-1}$ (phosphorus related, strong peak for dibutyl lead phosphite (DBLP)).

Backscattered SEM-EDX of PO6 (Fig 4d) revealed large particles of $\mathrm{CaCO}_{3}$ covered with smaller particles of lead stabilizer. Again dark and light flakes were detected. LIMA was performed on both the light and dark flakes; the light flakes were rich in sodium, calcium (filler) and titanium (pigment); the darker material contained species common to the stabilizer, e.g. lead and phosphorous. The sodium present in this sample could be attributed to sodium carbonate blowing agent. A small amount of calcium stearate was detected by DSC, while infra-red analysis detected mostly $\mathrm{CaCO}_{3}$ again with $\mathrm{CH}_{2}$ peaks, $\mathrm{C}=\mathrm{O}$ at $1736 \mathrm{~cm}^{-1}$ and $1566 \mathrm{~cm}^{-1}$ (probably due to calcium stearate) (Fig 6).

DSC analysis of $\mathrm{PO} 7$ revealed calcium stearate, and a peak at $104^{\circ} \mathrm{C}$, probably due to a hydrocarbon wax lubricant. This sample appeared to have been obtained during a purge cycle, as small quantities of purge material were present. EDX detected an abundance of chlorine with smaller quantities of calcium and sodium, suggesting that the material was predominantly foamed $\mathrm{PVC}$ and $\mathrm{CaCO}_{3}$ filler, with traces of blowing agent. The infra-red 
spectrum was predominantly $\mathrm{CaCO}_{3}$ with minor absorbances associated with calcium stearate. The different colored flakes present were examined by LIMA, and had different compositions as shown in Table 3.

Sample PO8 was from a Ca/Zn based formulation, with plate-out collected from the die. In this case DSC revealed a small melting peak at $125^{\circ} \mathrm{C}$, which could be due to zinc stearate from the stabilizer. Backscattered SEM (Fig 4f) shows a smeared but otherwise featureless sample. EDX of the general area showed strong calcium and titanium peaks. The zinc component of the stabilization package is only seen as a trace amount. Some small light particles (about $1 \mu \mathrm{m}$ in diameter) were also observed, and were found to be calcium, titanium or antimony. LIMA results in Table 3 show that the white colored material was mostly titanium with traces of lead. Iron and molybdenum were also visible. The orange stained material contained phosphorous. A relatively strong peak at $1560 \mathrm{~cm}^{-1}$ was also present in the IR spectrum. $\mathrm{CH}_{2}$ peaks were also present, as in PO5 and PO6. The coloration in PO8 can be attributed to chromium oxide that would have originated from the extrusion equipment; iron was also detected in the white component.

Samples PO3 to PO7 involved different extruders and products, but in all cases were lead stabilized, and in most cases involved die plate-out. Several previous workers [5-7] have proposed that oxidation of equipment (e.g. the extruder barrel [6]) contributed to plate-out. In the present work traces of iron and chromium were only detected for samples PO3 and PO8 despite using extremely sensitive techniques for detecting metallic substances. It appears that corrosion was not a major cause of plate-out for samples examined here. Ti from titanium oxide and $\mathrm{Ca}$ from calcium carbonate, together with lead phosphite and/or sulfate were found in all die plate-out samples. Small amounts of lubricant (calcium stearate or waxes) were 
present in all cases, supporting the proposal that they were functioning as carriers.

Miscellaneous additives such as blowing agents and flame retardants could also be observed. Results here show that the lubricants have a key role in plate-out; in the second part of this paper the effects of different lubricant types will be considered.

\section{Conclusions}

The combination of a number of characterization techniques is invaluable for this type of analysis. FTIR and DSC were used to identify organic components. FTIR was also useful for identifying some inorganic compounds present in sufficient quantities, while EDX detected elements present. LIMA was the most sensitive technique, detecting trace quantities of both cations and anions. In general the different techniques provided support for one another. The calibrator plate-out was mainly organic. Main components of the die plate-out for lead stabilized compounds were titanium from $\mathrm{TiO}_{2}$, calcium from calcium carbonate and lead stabilizers. Small amounts of lubricant (calcium stearate or waxes), which would be molten at extrusion temperatures, were also present, supporting the proposal that they were acting as carriers for the inorganics. In a second paper the effects of different lubricant types will be examined. PVC itself is not generally detected in plate-out samples.

It was also observed that corrosion of the extruder barrel was not a major cause of plate-out for samples examined here. 


\section{References}

1. J. Parey 'Plate-Out in flow channels in PVC Extrusion', Conference Proceedings, IKV Colloquium, Aachen, March 1980, 432-436.

2. J. Parey 'Plate-Out - Cause and Remedy', Kunststoffberater, 4, 39-40 (1980).

3. B. R. O. Pointer, 'Extrusion of Unplasticised PVC: A study of plate-Out Phenomena', Internal report PL/510/B, Imperial Chemical Industries Ltd, PVC Division, Welwyn Garden City, 1-20.

4. R. F. Lippoldt, 'How to avoid plate-out in extruders', Plastics Engineering, September 1978, 37-39.

5. P. J. Leskovyansky, 'Testing for Plate-Out Using the Torque Rheometer', J. Vinyl. Tech., 6 82-84 (1984).

6. G. Bussman, H. Ruse and B. Herr, 'Plate-Out in PVC Processing', Kunstoffe, 88, 21542157 (1998).

7. A. Bos, T. Huelsmann, S. Juergens and M. Sander, 'Plate-out in Extrusion', Conference Proceedings, New Techniques in Extrusion, Würzburg, 1999.

8. D. A. Holtzen and J. A. Musiano, 'Die Lip Plate-Out - a proposed mechanism', Du Pont Technical Updat.e

9. M. Schiller, A. Egger and P. Stern, 'Profile, Produktion, Probleme - eine unvermeidbare Dreieinigkeit?', Conference proceedings, New Techniques in Extrusion, Würzburg, 2000 Beispiel 3.

10. M. Schiller, B. Pelzl, R. Haberleitner, H. Huisman; "Plate out - A problem without hope?" Plastic Profiles in Construction, Brussels, November 2006

11. W. V. Titow, Chapter 4 in PVC Plastics - Properties, Processing and Applications, Elsevier Applied Science, London and New York, 1990.

12. E. J. Wickson and R. F. Grossman, Chapter 28 in Handbook of PVC formulating, ed W. V. Titow, John Wiley and Sons, New York, 1993.

13. M Gilbert, N Varshney K Van Soom M Schiller IOM Conf. Proc. International PVC Conference, Brighton, April 2002, 157-165.

14. I. Szarvasy and J.F.T. Pittman, Polym. Eng. \& Sci., 43, 1488 (2003).

15. J. Clarke and D. Gerlach, Conf. Proc. Current Trends in PVC Technology, Loughborough 2003. 
Table 1. Plate-out samples collected

\begin{tabular}{|c|c|c|c|c|c|}
\hline $\begin{array}{c}\text { Sample } \\
\text { No. }\end{array}$ & Description & $\begin{array}{l}\text { Formulation } \\
\text { Information }\end{array}$ & Application & Location & $\begin{array}{c}\text { Time to } \\
\text { formation }\end{array}$ \\
\hline PO1 & $\begin{array}{l}\text { waxy } \\
\text { multicolored } \\
\text { flakes }\end{array}$ & lead stabilizer & wall panels & $\begin{array}{l}\text { calibration } \\
\text { unit }\end{array}$ & 4-6 hours \\
\hline PO3 & dark grey & lead stabilizer & unknown & unknown & unknown \\
\hline PO4 & $\begin{array}{l}\text { sandy colored } \\
\text { residue }\end{array}$ & $\begin{array}{l}\text { lead stabilizer, one } \\
\text { pack system, } 1.5 \mathrm{phr} \\
\mathrm{TiO}_{2}, 1.5 \mathrm{phr} \mathrm{CaCO}_{3}\end{array}$ & pipe & $\begin{array}{l}\text { chromed pin } \\
\text { (deep in die } \\
\text { head) }\end{array}$ & 24 hours \\
\hline PO5 & white/green flakes & $\begin{array}{l}\text { lead stabilizer, one } \\
\text { pack system, } 1.5 \mathrm{phr} \\
\mathrm{TiO}_{2}, 1.5 \mathrm{phr} \mathrm{CaCO}_{3}\end{array}$ & pipe & chromed pin & 24 hours \\
\hline PO6 & $\begin{array}{l}\text { dark \& light } \\
\text { flakes/powder }\end{array}$ & $\begin{array}{l}\text { lead stabilizer, } \\
\text { lubrication unknown }\end{array}$ & foam & mandrel & unknown \\
\hline PO7 & $\begin{array}{l}\text { larger flakes than } \\
\text { PO6 }\end{array}$ & $\begin{array}{l}\text { lead stabilizer, } \\
\text { lubrication unknown }\end{array}$ & foam & mandrel & unknown \\
\hline PO8 & $\begin{array}{l}\text { light colored } \\
\text { flakes, some with } \\
\text { orange tinge }\end{array}$ & $\begin{array}{c}\text { calcium/zinc stabilizer, } \\
\text { PE lubricant }\end{array}$ & unknown & die & 5 days \\
\hline
\end{tabular}


Table 2. Analysis of Plate-out samples

\begin{tabular}{|c|c|}
\hline Sample & Analysis Summary \\
\hline $\begin{array}{c}\text { PO1 } \\
\text { (dark) }\end{array}$ & $\begin{array}{l}\text { Melting peaks at } 40 \text { and } 52^{\circ} \mathrm{C} \text { due to fatty alcohol or stearyl stearate; also at } 89^{\circ} \mathrm{C} \text { LIMA } \\
\text { showed Ca and Ti present, and lower concentration of Pb. It also detected } \mathrm{La} \text {, Ce and Nd, } \\
\text { possibly associated with Ti from } \mathrm{TiO}_{2} \text {, and } \mathrm{PO}_{2}, \mathrm{PO}_{3} \text { possibly from lead phosphite. FTIR } \\
\text { confirms } \mathrm{CH}_{2} \text { and } \mathrm{C}=\mathrm{O} \text { groups, and phosphite. } \mathrm{Cl} \text { was also detected by LIMA and EDX, but } \\
\text { not as a major component. }\end{array}$ \\
\hline $\begin{array}{c}\text { P01 } \\
\text { (light) }\end{array}$ & As PO1 except melting peak at $92^{\circ} \mathrm{C}$ absent. \\
\hline PO3 & $\begin{array}{l}\text { No melting peaks observed. Flaky particulates observed on a substrate. Flakes showed strong } \\
\text { presence of } \mathrm{Pb}, \mathrm{P}, \mathrm{S} \text {, Cl. Substrates showed strong presence of Ti. LIMA also showed Ca and } \\
\mathrm{Ba} \text {, and } \mathrm{Fe} \text { and } \mathrm{Cr} \text { suggesting corrosion of extrusion equipment. Main FTIR peaks due to } \\
\mathrm{C}=\mathrm{O} \text { and } \mathrm{C}-\mathrm{O}-\mathrm{C} . \mathrm{CH}_{2} \text { peaks weak. }\end{array}$ \\
\hline PO4 & $\begin{array}{l}\text { Melting peak at } 132^{\circ} \mathrm{C} \text { typical of calcium stearate. SEM shows flakes with parallel lines } \\
\text { possibly due to scraping along die. Flakes show } \mathrm{Pb} \text { strongly; background } \mathrm{TiO}_{2} \text { and } \mathrm{CaCO}_{3} \text {. } \\
\text { LIMA shows } \mathrm{Pb}, \mathrm{Ti} \text {, and Ca. FTIR spectrum mainly due to calcium carbonate and calcium } \\
\text { stearate, and weak } \mathrm{CH}_{2} \text { peaks. }\end{array}$ \\
\hline PO5 & $\begin{array}{l}\text { No melting peaks observed. LIMA and EDX analysis similar to PO4, showing Pb, Ti, and Ca } \\
\text { strongly. However, SEM showed particles to be much finer. FTIR mainly calcium carbonate, } \\
\text { but } \mathrm{CH}_{2}, \mathrm{C}=\mathrm{O} \text { and } \mathrm{C}-\mathrm{O}-\mathrm{C} \text { also present, possibly due to an ester lubricant. }\end{array}$ \\
\hline PO6 & $\begin{array}{l}\text { Melting peak at } 132^{\circ} \mathrm{C} \text { due to calcium stearate. SEM shows large flakes of calcium carbonate } \\
\text { and small particles containing } \mathrm{Pb} \text {. No } \mathrm{TiO}_{2} \text { was detected, but Ti was found, together with } \mathrm{Ca} \\
\text { and } \mathrm{Pb} \text { by LIMA. FTIR mainly calcium carbonate, but } \mathrm{CH}_{2} \text { and additional peaks also present. }\end{array}$ \\
\hline PO7 & $\begin{array}{l}\text { Melting peaks at } 135^{\circ} \mathrm{C} \text { due to calcium stearate and } 83^{\circ} \mathrm{C} \text {, possibly due to a wax. SEM } \\
\text { showed a rather featureless structure with particles of various sizes. EDX provided evidence } \\
\text { for } \mathrm{Ca} \text { and } \mathrm{Cl} \text {, suggesting that this sample was mainly } \mathrm{PVC} \text { and } \mathrm{CaCO}_{3} \text {. Different colored } \\
\text { regions were sampled by LIMA. Darkest regions included Ti, also } \mathrm{Al}, \mathrm{K} \text { and Na, probably as } \\
\text { contamination. Among the negative ions, chlorine was strong and small chain molecules } \\
\text { were also detected. Brown regions were similar, except that associated lanthanide elements } \\
\text { and Pb were also detected. White regions contained lead phosphite and sulphate stabilizers. } \\
\text { Again, the FTIR spectrum was mainly due to calcium carbonate. }\end{array}$ \\
\hline PO8 & $\begin{array}{l}\text { Small melting peak at } 122^{\circ} \mathrm{C} \text {, which remains on re-melting, unlike that for calcium stearate. } \\
\text { Source unknown. SEM shows a smeared, but otherwise featureless sample, with EDX } \\
\text { showing a strong Ca peak. Small particles present showed evidence of Ti and Sb, possibly } \\
\text { from antimony trioxide. White and orange samples were examined by LIMA. White colored } \\
\text { material was mainly Ti, with traces of Pb, Fe and Mo from extruder. Pb was also detected in } \\
\text { orange regions, and the orange color was believed to be due to Cr. FTIR spectrum was } \\
\text { mainly calcium carbonate, but } \mathrm{CH}_{2} \text { and } \mathrm{COO}^{-} \text {peaks also present. }\end{array}$ \\
\hline PO9 & $\begin{array}{l}\text { Only observed melting peak was at } 83^{\circ} \mathrm{C} \text { possibly due to paraffin from lubrication system, as } \\
\text { in PO7. SEM showed large flakes, mainly due to PVC, and small particles, variously found } \\
\text { by EDX to be } \mathrm{Cr} \text { from extruder, Pb, Ba and Sb. LIMA showed Ca, Ti and sulfite and } \\
\text { phosphite groups. Once again, FTIR spectrum was mainly due to calcium carbonate, with } \\
\text { additional peaks due to } \mathrm{CH}_{2} \text { and }\left(\mathrm{CH}_{2}\right)_{\mathrm{n}} \text {, the latter due to paraffin. }\end{array}$ \\
\hline P10 & Similar to PO8. \\
\hline
\end{tabular}


Table 3 LIMA analysis of sample PO7

\begin{tabular}{|c|c|c|c|c|}
\hline Sample & \multicolumn{2}{|c|}{ Cations } & \multicolumn{2}{|l|}{ Anions } \\
\hline \multirow{4}{*}{ White } & $\mathrm{Na}$ & & $\overline{C_{2}}$ & $\overline{C_{6}}$ \\
\hline & $\mathrm{Na}_{2} \mathrm{Cl}$ & & $\mathrm{C}_{3}$ & $\mathrm{CaCl}_{3}$ \\
\hline & $\mathrm{Ca}$ & & $\mathrm{C}_{4}$ & $\mathrm{Cl}$ \\
\hline & $\mathrm{Ti}$ & & $\mathrm{C}_{5}$ & $\mathrm{NaCl}_{2}$ \\
\hline \multirow{4}{*}{ Dark } & $\mathrm{Ca}$ & $\mathrm{NaKCN}$ & $\mathrm{C}_{4}$ & $\mathrm{CN}$ \\
\hline & $\mathrm{Na}$ & $\mathrm{Ti}$ & $\mathrm{C}_{5}$ & CNO \\
\hline & $\mathrm{Na}_{2} \mathrm{CN}$ & TiO & $\mathrm{C}_{6}$ & \\
\hline & $\mathrm{Na}_{2} \mathrm{O}$ & & $\mathrm{Cl}$ & \\
\hline \multirow{7}{*}{ Brown } & $\mathrm{Ca}$ & $\mathrm{Na}$ & $\mathrm{CN}$ & \\
\hline & $\mathrm{CaCl}$ & $\mathrm{Na}_{2} \mathrm{Cl}$ & $\mathrm{Cl}$ & \\
\hline & $\mathrm{CaOH}$ & $\mathrm{Nd}$ & $\mathrm{NaCl}_{2}$ & \\
\hline & $\mathrm{Ce}$ & $\mathrm{Pb}$ & & \\
\hline & $\mathrm{CeO}$ & $\mathrm{PbO}$ & & \\
\hline & $\mathrm{La}$ & $\mathrm{Ti}$ & & \\
\hline & $\mathrm{LaO}$ & TiO & & \\
\hline
\end{tabular}




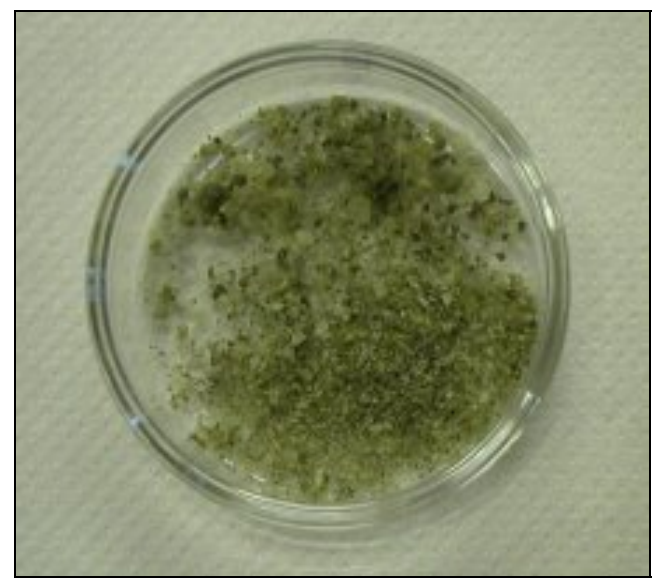

1. Fig 1 Plate-out sample PO1 


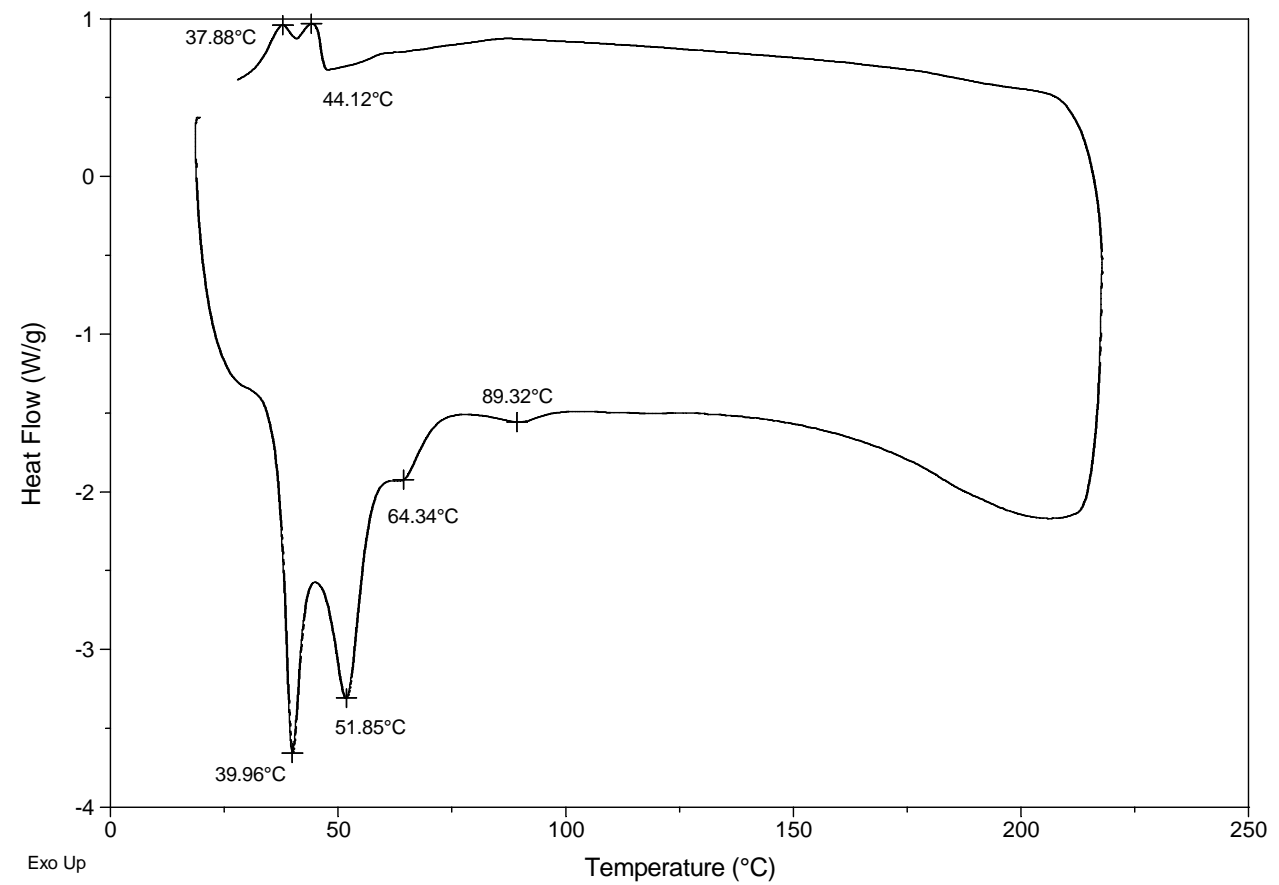

2. Fig 2 DSC trace of dark material in sample PO1 


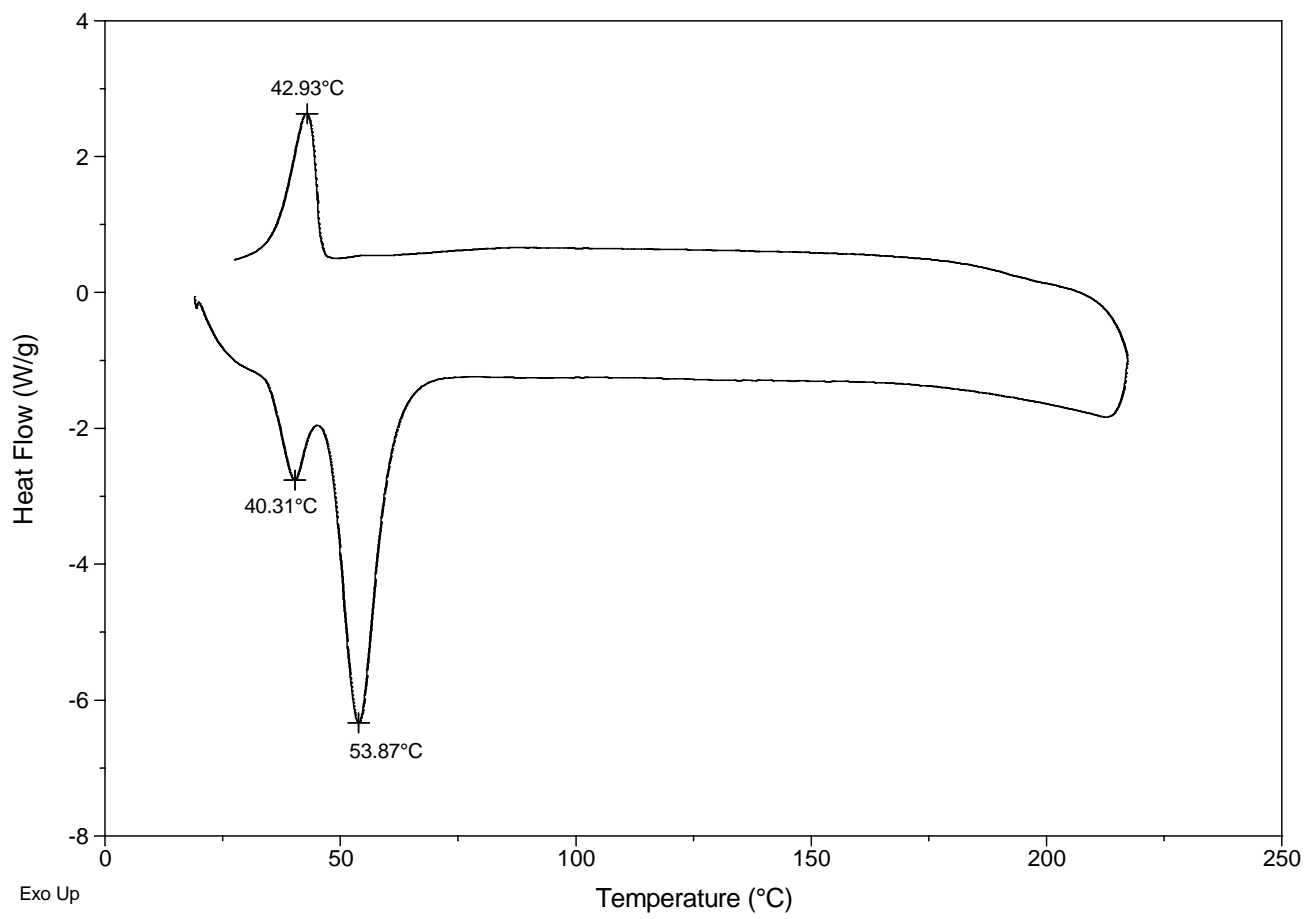

3. Fig 3 DSC trace of dark material in sample PO1 

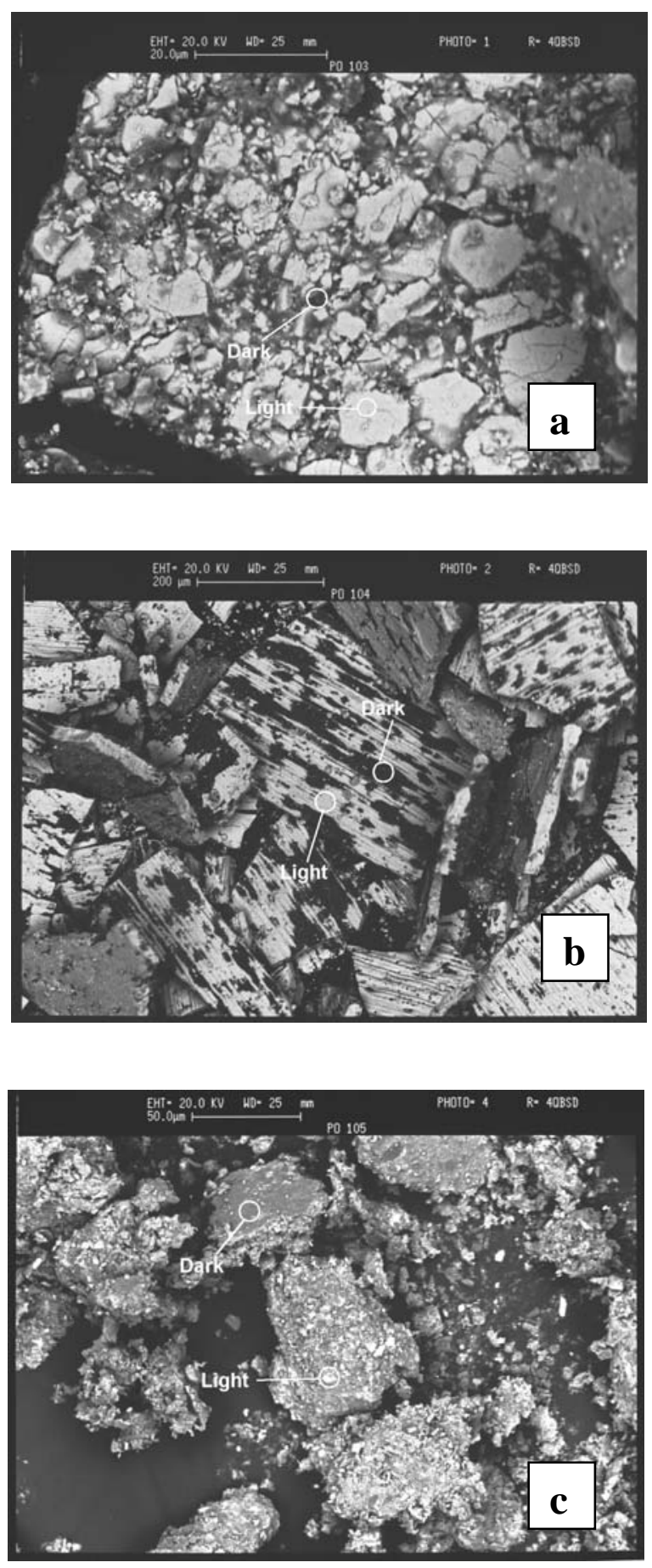

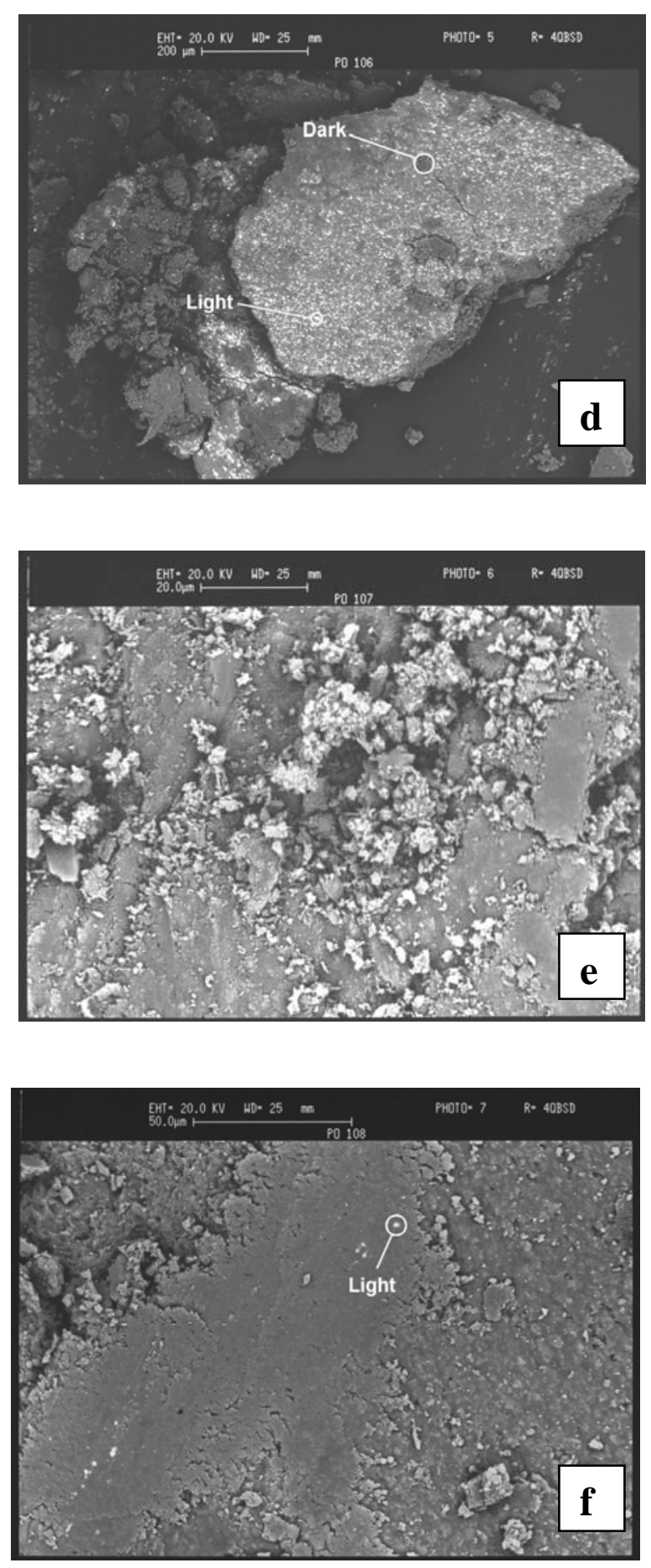

Fig 4 Backscattered SEM image of (a) PO3; (b) PO4; (c) PO5; (d) PO6; (e) PO7; (f) PO8 


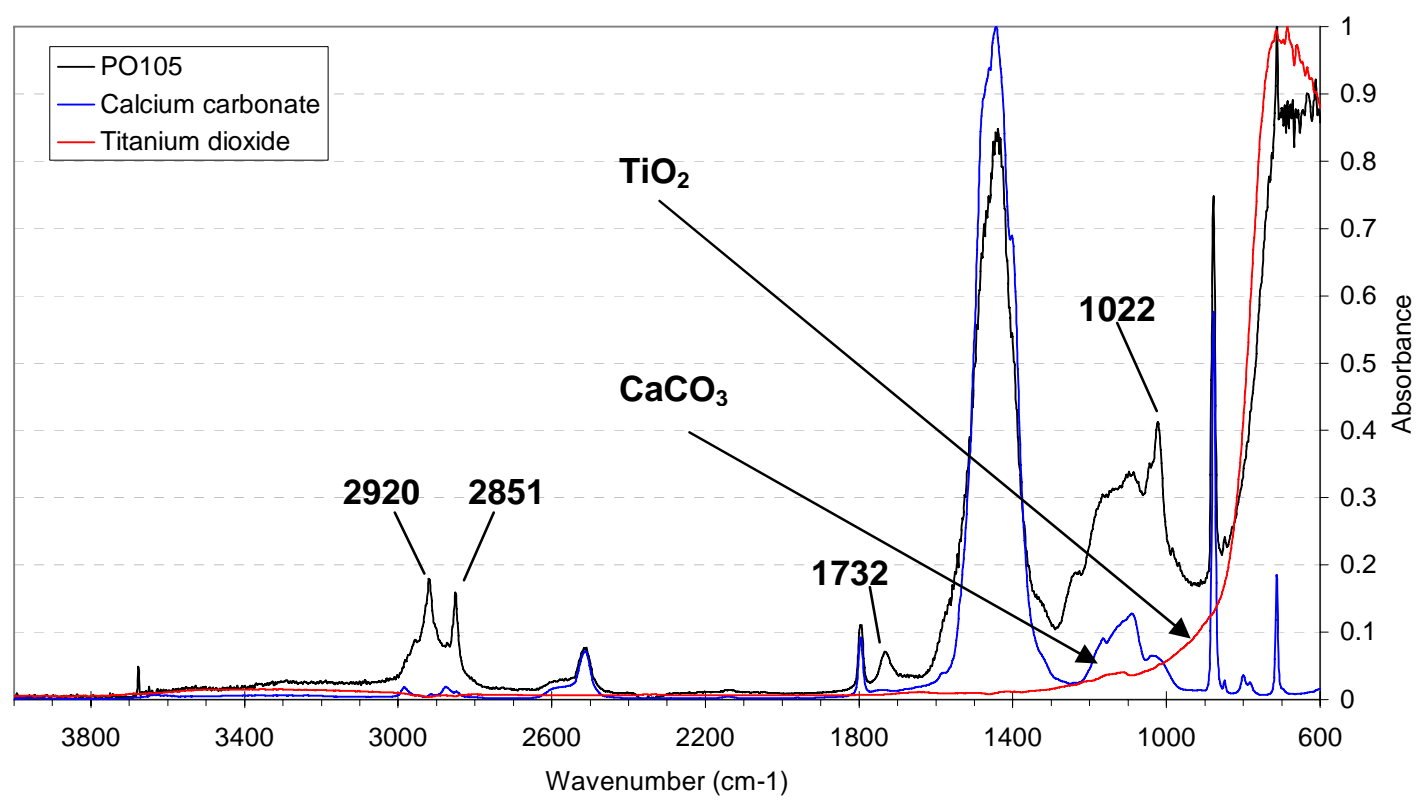

4. Fig 5 FTIR spectrum of sample PO5 


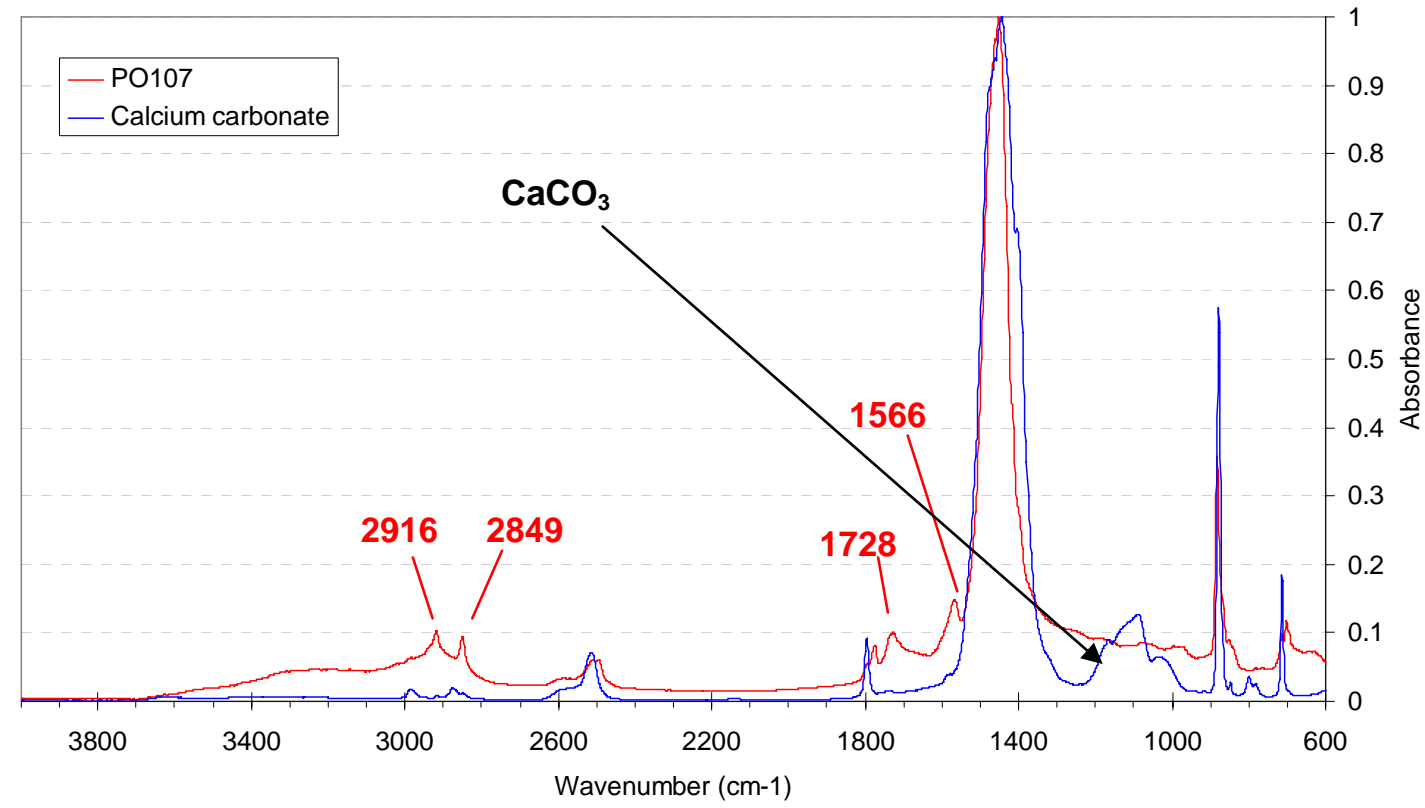

5. Fig 6 FTIR spectrum of sample PO 